\title{
Hydrological studies in experimental and representative basins in Pernambuco State, Brazil
}

\author{
SUZANA M. G. L. MONTENEGRO ${ }^{1}$, BERNARDO B. DA SILVA ${ }^{1}$, \\ ANTÔNIO C. D. ANTONINO ${ }^{1}$, JOSÉ R. S. LIMA ${ }^{2}$, EDUARDO S. DE SOUZA ${ }^{3}$, \\ LEIDJANE M. M. DE OLIVEIRA ${ }^{1}$, ALBERT E. S. S. DE MOURA ${ }^{1}$ \\ \& RODOLFO M. S. SOUZA ${ }^{3}$ \\ 1 Federal University of Pernambuco, UFPE, Civil Engineering Department, Av. Acadêmico Hélio Ramos, s/n. Cidade \\ Universitária. Recife, PE, Brazil \\ suzanam@ufpe.br \\ 2 Rural Federal University of Pernambuco, Academic Unit of Garanhuns, Avenida Bom Pastor, s/n, Boa Vista, CEP: \\ 55292-270, Garanhuns/PE, Brazil \\ 3 Rural Federal University of Pernambuco, Academic Unit of Serra Talhada, Fazenda Saco s/n CEP: 56900-000, Serra \\ Talhada, PE, Brazil
}

\begin{abstract}
Hydrological studies in experimental and representative basins are of fundamental importance for water resources management. This paper presents some activities of hydrological research in experimental and representative basins of the State of Pernambuco, Brazil. The study areas are located at Tapacurá and Mundaú representative basins and at the Gameleira experimental basin, and in experimental plots in Pajeú basin. In the Tapacurá basin, three studies were performed: (1) different monthly coefficients " $k$ " of the Thornthwaite method were tested to calculate the effective temperature and, consequently, the reference evapotranspiration, giving rise to the method identified as Modified Thornthwaite; (2) the spatial variability of the retention curve and hydraulic conductivity parameters were analysed using the Beerkan method; (3) changes in vegetation cover were evaluated through the NDVI and NDWI indexes using TM-Landsat 5 images. In the Mundaú representative basin, the performance of different evapotranspiration methods was evaluated and compared to the FAO standard method, Penman-Monteith. In the Pajeú basin, the experimental plot is covered by pasture and sensors were installed to monitor the following variables: rainfall, air temperature, the energy balance components (net radiation, latent and sensible heat, and soil heat flux), wind velocity and $\mathrm{CO}_{2}$ flux into atmosphere, soil moisture and runoff.
\end{abstract}

Key words: Beerkan, evapotranspiration, water balance, energy balance, $\mathrm{CO}_{2}$ flow

\section{INTRODUCTION}

A fundamental aspect for adequate water resources management is the knowledge of hydrological quantities like evapotranspiration, hydraulic conductivity, etc. In the State of Pernambuco, Brazil, the poorest state in terms of water availability, scientific research related to water resources has been conducted in Tapacurá, Mundaú and Pajeú basins. These studies were led by UFPE (Federal University of Pernambuco) and UFRPE (Federal Rural University of Pernambuco). Representative basins are instrumented basins with appliances observation and recording of hydrological and climatological phenomena and represent basins located in the same homogeneous region. It is of great importance to study the hydrological processes that occur in these basins, because these basins are representative in Pernambuco State and are located in areas of water scarcity, mainly in Mandau and Pajeú basins. Tapacurá basin contributes to the water supply of the Recife Metropolitan Region (the capital city) and extends from the coast to the beginning of the semi-arid region. Within the Tapacurá representative basin is the Gameleira experimental basin, where several studies are conducted in the context of hydrology.

The objective of this work is to show the results obtained in different studies of hydrological processes performed in the Mundau, Pajeú and Tapacurá basins in the State of Pernambuco, Brazil.

\section{DATA AND METHODS}

The research was conducted in three study areas: Tapacurá, Mundaú and Pajeú basins. The dominant weather in Tapacurá basin is a pseudo tropical hot and humid climate according to Köeppen classification. The average annual rainfall is $1047 \mathrm{~mm}$, the average monthly temperature ranges between 23.7 and $27.0^{\circ} \mathrm{C}$, while the relative humidity during the months from March to July, is over 


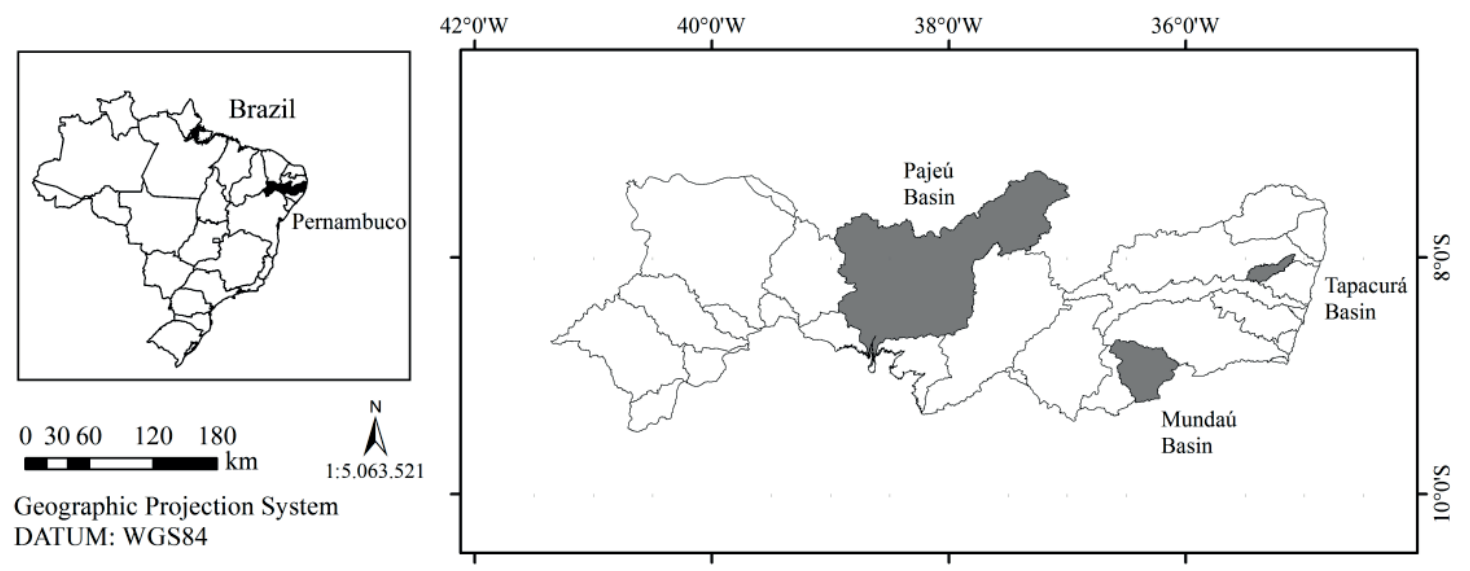

Fig. 1 Location of Pajeú, Mundaú and Tapacurá basins in Pernambuco, Brazil.

$70 \%$ (Silva et al. 2010). Mundaú basin is located in the arid zone and has an area of $4126 \mathrm{~km}^{2}$ area, of which $52.2 \%$ is in Pernambuco State and $47.8 \%$ is in Alagoas State. The Mundaú River rises in the city of Garanhuns and has about $69 \mathrm{~km}$ of extension. The Pajeú basin is located in the hinterland in the semi-arid region and is the largest watershed in Pernambuco State, where rainfed cultivation and livestock are the main economic base of the region.

In order to determine the reference evapotranspiration (ETo) and comparing methodologies in Tapacura basin the following were used: (1) the equation of Penman-Monteith FAO-56 (Allen et al. 1998, Moura et al. 2012), (2) the equation proposed by Thornthwaite concerning the exponential relationship between mean monthly temperature and evapotranspiration (Thornthwaite 1948, Pereira and Pruitt 2004), (3) the Modified Thornthwaite method (Pereira and Pruitt 2004); and (4) the method of Thornthwaite with variable $k$ (Moura et al. 2012).

In Tapacura basin, two Thematic Mapper (TM), Landsat 5 images, orbit 214 and path 66, to determine NDVI and NDWI were used. Through these the vegetation changes were evaluated. Each TM scene is composed by seven spectral bands and it is available at the National Institute for Space Research (INPE). They were obtained in 10 July 1989 and 29 August 2007. In order to obtain the vegetation index NDVI and NDWI, at first the spectral radiance was calculated by applying the Markham and Baker (1987) equation; then, the reflectance for each spectral band was determined following the methodology used by Allen et al. (2002). The NDVI shows a range between -1 and +1 , and is given by: NDVI $=\left(\rho_{\mathrm{IV}}-\rho_{\mathrm{V}}\right) /\left(\rho_{\mathrm{IV}}+\rho_{\mathrm{V}}\right)$, where $\rho_{\mathrm{IV}}$ and $\rho_{\mathrm{V}}$ area the reflectance for the infrared (band 4) and red (band 3) TM bands (Rouse et al. 1973). The NDVI of vegetated surfaces ranges from 0 to 1 and for water or clouds dominate values less than zero. The NDWI was obtained by the ratio between 4 and 5 TM bands, according to the equation (Gao 1996): NDWI $=\left(\rho_{\mathrm{IV}}-\rho_{\mathrm{mir}}\right) /\left(\rho_{\mathrm{IV}}+\rho_{\mathrm{mir}}\right)$, corresponding to the near-infrared bands $\left(\rho_{\mathrm{IV}}\right)$ with wavelengths between 0.76 and $0.79 \mu \mathrm{m}$ and infrared ( $\rho_{\text {mir }}$ ), with wavelengths between 1.55 and $1.75 \mu \mathrm{m}$.

The Beerkan method was used to obtain equation parameters of the soil water retention curve (Van Genuchten 1980) and hydraulic conductivity curve (Brooks and Corey 1964) in Tapacurá basin. The spatial variability of parameters was analysed by semivariogram adjustments. Maps of the spatial distribution of shape and standardization parameters of the retention curve $\theta(\mathrm{h})$ and hydraulic conductivity $\mathrm{K}(\theta)$ were produced by using geostatistical analysis by applying ordinary kriging.

In the Pajeú basin, two periods (wet season: from 27 April 2013 to 12 May 2013 and dry season: 21 September 2013 to 6 October 2013) were selected to represent the wet and dry periods in this region. In each measured period the fluctuations of $\mathrm{CO}_{2}$ flow, and the water and energy balance components were considered.

In Mundaú basin, the study site was located at the "Riacho do Papagaio Farm", São João count in Pernambuco State. The study was conducted in 2011. A micro-meteorological tower was established in the centre of the experimental field, and sensors were installed to measure evapotranspiration. We used FAO Penman-Monteith (Allen et al. 1998), Camargo (1971), Hargreaves-Samani (1985), Jensen-Haise (1963) and Makkink (1957) methods. 


\section{RESULTS AND DISCUSSION}

Reference evapotranspiration by Thornthwaite methods Figure 1 shows the results of applying the methods of Thornthwaite, Modified Thornthwaite and Penman-Monteith FAO-56. for the Thornthwaite Modified method we used two values of the "k" coefficient: 0.69 and 0.72 (Camargo et al. 1999, Pereira and Pruitt 2004, Fernandes 2006, Back 2008).

Due to the wet season, which occurs from April to August, it was shown in Fig. 2 that the evapotranspiration is lowest in this period. Using " $\mathrm{k}$ " coefficients equal to $0.69,0.72$ the results underestimated the evapotranspiration in all months of the year compared with the standard method of Penman-Monteith FAO-56. With the use of different monthly coefficients (variable $\mathrm{k}$ coefficients), the results are even better than those obtained with $\mathrm{k}=0.72$ and 0.69 and the original Thornthwaite method. The use of these coefficients for the studied area accentuated the behaviour of the original Thornthwaite method in order to minimize the evaporation even more. The results showed standard error of estimate of $0.475,0.915,0.637$ and $0.281 \mathrm{~mm} \mathrm{~d}^{-1}$ for the Thornthwaite original method, "k" coefficient equal to 0.69 , "k" coefficient equal to 0.72 and Modified Thornthwaite method, respectively.

NDVI and NDWI indexes using TM - Landsat 5 images It is noted that NDVI classes with lower values (0.00 to 0.20), located in urban areas of Pombos and Vitoria de Santo Antão (Fig. 3), configure stressed vegetation or degraded area by human action, arising out of water scarcity, which results in the exposure of the soil to deforestation and environmental degradation.

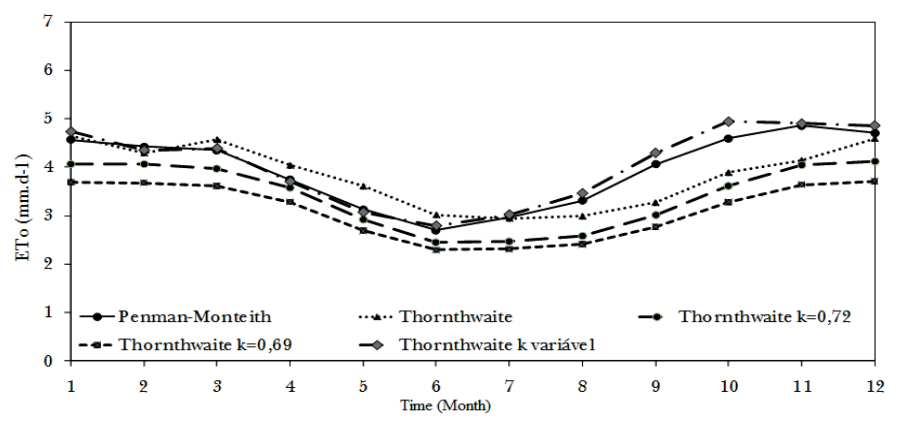

Fig. 2 Evapotranspiration calculated by different methods in Tapacurá basin.
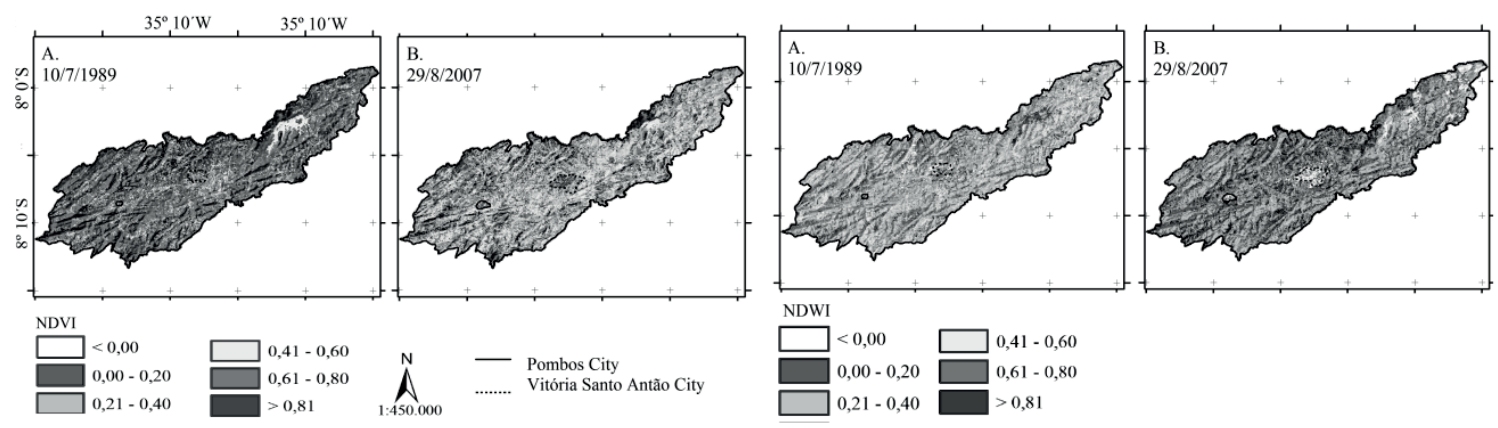

Fig. 3 Vegetation Index (NDVI) and Water Index Normalized Difference (NDWI) in Tapacurá basinPE.

Higher values of NDWI were shown to be associated with vegetation which has high water content in its internal structure. In contrast, the lowest values are indicative of the vegetation which contains less water. Even in the comparative analysis between the two indexes, the highest values, as expected, showed up close to flooded areas of the Tapacurá Reservoir, most clearly seen at coordinates $8^{\circ} 02^{\prime}$ south latitude and $35^{\circ} 11^{\prime}$ west longitude). These high values found in riparian vegetation are represented in both the NDVI and the NDWI; it also indicates that those areas are comprised of photosynthetically active vegetation. They also have high moisture content due to the proximity of water bodies. 
Spatial variability of the retention curve and hydraulic conductivity parameters, using the Beerkan method (Haverkamp et al. 1994, Braud et al. 2005, Lassabatère et al. 2006): as well as in most studies in soil science (e.g. Vieira 1997, Souza et al. 2001, Carvalho et al. 2002), the spherical model was the best fit.

The maps of the spatial distribution of shape and standardization parameters of retention and hydraulic conductivity curves are shown in Fig. 4.

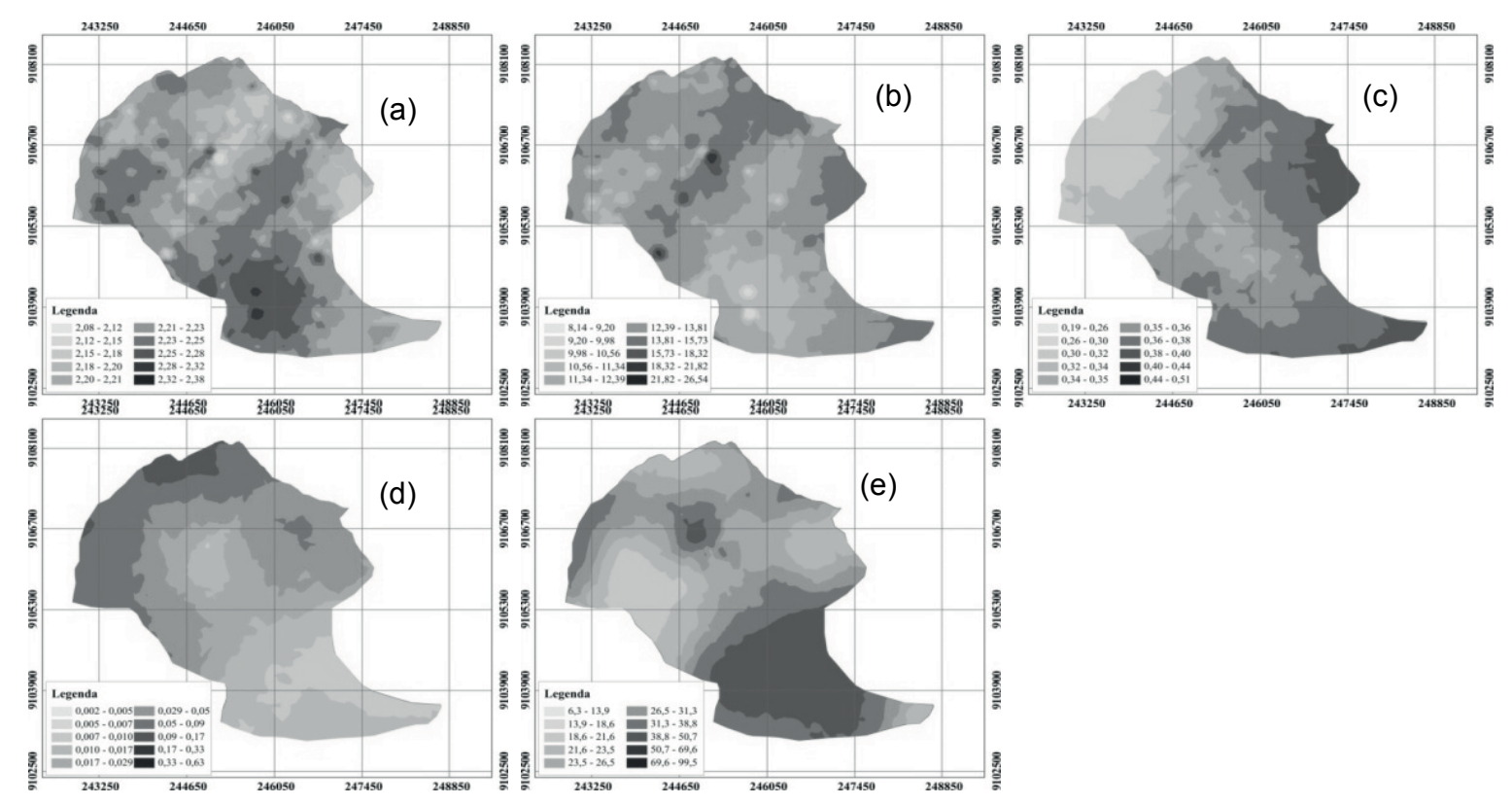

Fig. 4 Spatial distribution maps of the studied parameters in Gameleira basin (Tapacurá sub basin): (a) and (b) are shape parameters $n$ and $\eta$, respectively, and (c), (d) and (e) are standardization parameters, $\theta_{\mathrm{s}}$, $\mathrm{K}_{\mathrm{s}}$ and $\mathrm{h}_{\mathrm{g}}$.

The observed and estimated average of all evaluated parameters showed no significant differences at the 0.05 level of probability. The Beerkan method has proved to be a promising tool, robust and easy to use, which can help parameterization of hydrological models of physical and distributed types. Souza et al. (2008) found $n$ values in the interval 2.15 to 2.36, in an alluvial soil and 2.16 to 2.23 on an Oxisol. Souza (2005) studied two experimental areas with beans grown in the State of Paraíba, with $\eta$ observed values range from 7.5 to 15.5 and 9.5 to 15 . Silva et al. (2009) analysed soil samples with different textural classes (sand, sand and sandy frank frank) found for the parameter $\theta_{\mathrm{s}}$ values with amplitudes from 0.28 to $0.53 \mathrm{~cm}^{3} \mathrm{~cm}^{-3}$ in the Guaraíra basin. Souza et al. (2008) analysed soil samples with different textural classes and reported values for the parameter $\mathrm{hg}$ with ranging from 12.25 to $84.30 \mathrm{~mm}$.

Energy and water balance components and $\mathrm{CO}_{2}$ fluxes During the wet season (from March to May) when the grass (Urochloa mosanbicensis) was in full stage photosynthesis, $\mathrm{CO}_{2}$ values were near $-11 \mathrm{mmol} \mathrm{m} \mathrm{m}^{-1}$ between 11:00 and 13:00 hours (local time). This value is similar to that reported by von Randow et al. (2004) for pasture in the Amazon forest, Brazil. During dry fluctuations $\mathrm{CO}_{2}$ flux showed lower magnitude throughout the day. It is observed that during the night respiration (positive values) $\mathrm{CO}_{2}$ values were approximately three times greater for the wet season compared to the dry season (from June to February) (Fig. 5(a)). The water balance components are presented in Fig. 5(b). During the wet season there was $23 \mathrm{~mm}$ of rain, of which $76.24 \%$ of this rain were converted into $29.09 \%$ evapotranspiration and runoff. In pastures, where the soil tends to have high densities of soil due to animal grazing, runoff can reach $54.53 \%$ of rainfall (Costa et al. 2013). As no rain was recorded during the dry season, evapotranspiration was considered equal to the variation of water storage in the soil.

The daily fluxes of the energy balance components are shown in Fig. 6. The ratio LE/Rn indicates the fraction of the net radiation used in the evapotranspiration process. During the wet 

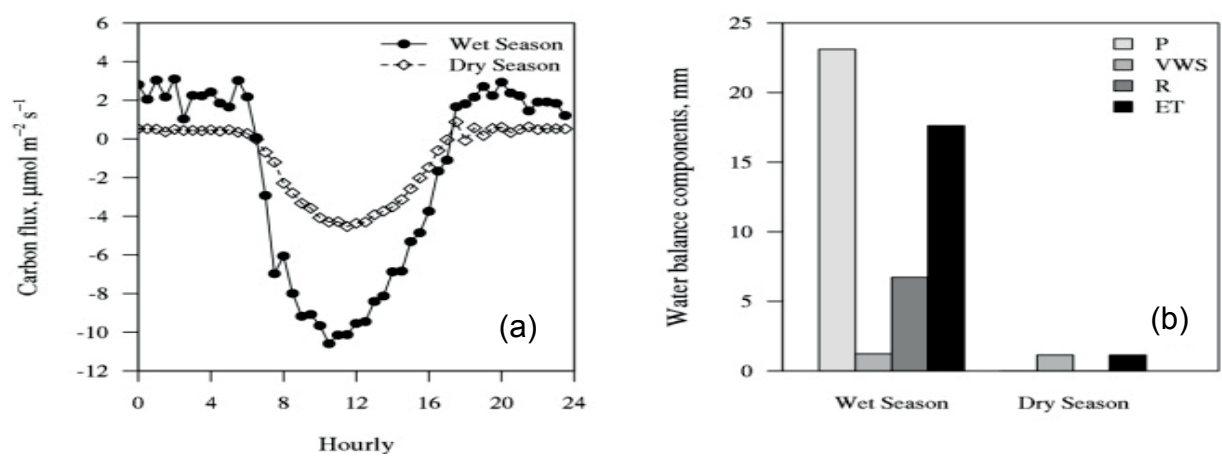

Fig. 5 (a) daily flow of $\mathrm{CO}_{2}$ in the wet and dry seasons; (b) water balance components in the wet and dry seasons in grassland.

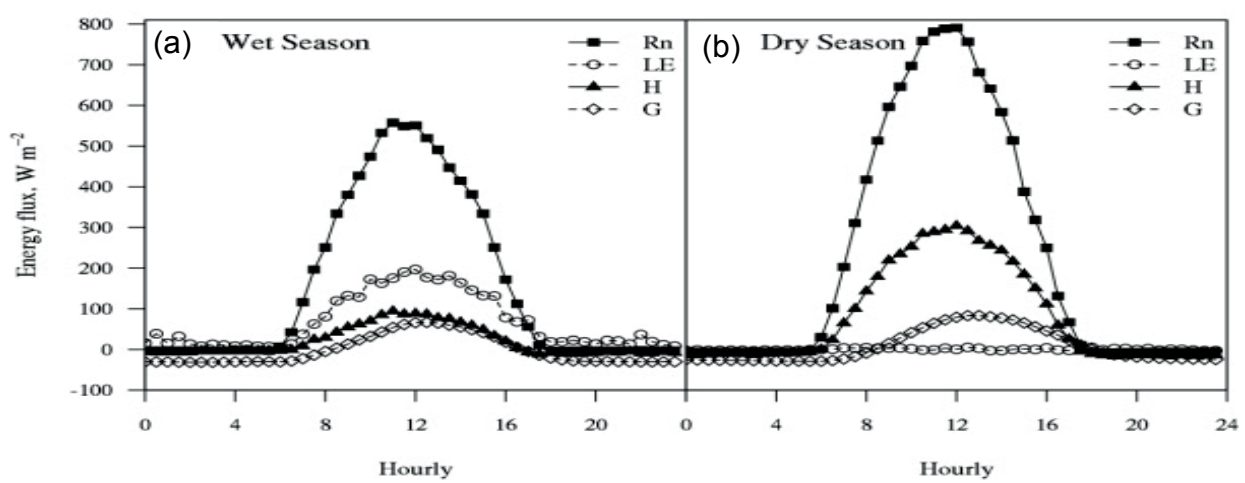

Fig. 6 Energy balance components: (a) wet season, (b) dry season.
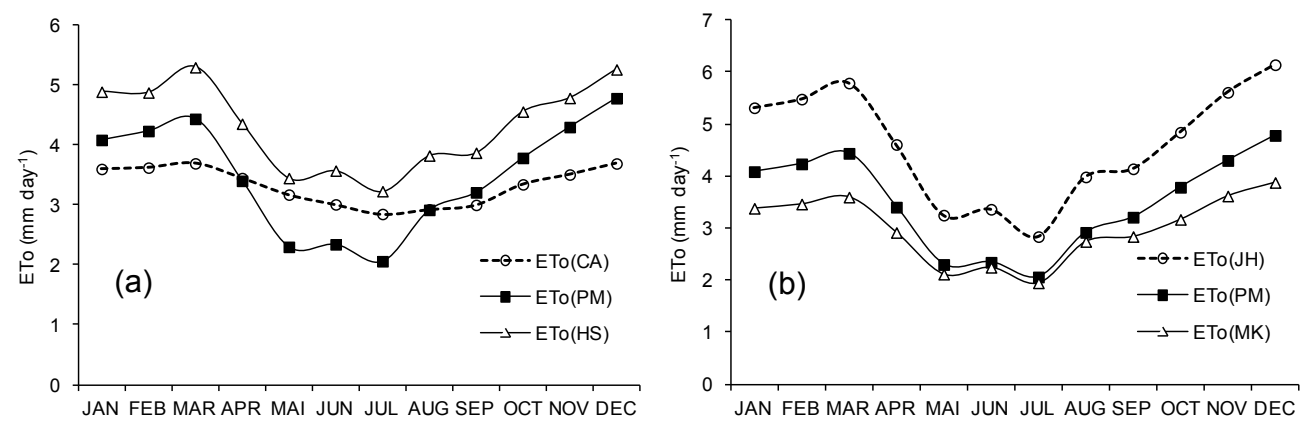

Fig. 7 (a) Comparison of mean monthly ETo calculated from the FAO PM model and the temperaturebased methods in São João, Pernambuco, Brazil, during the 2011 growing season. (b) Comparison of mean monthly ETo calculated from the FAO PM model and the radiation-based methods in São João, Pernambuco, Brazil, during the 2011 growing season. (CA), Carmargo; (PM), Penman-Monteith; (HS), Hargreaves-Samani; (JH), Jensen-Haise; (MK), Makkink.

season, the ratio $\mathrm{LE} / \mathrm{Rn}$ equal to 0.429 indicates great water availability in the soil and that the largest fraction of the net radiation was converted in the evapotranspiration process (Fig. 6(a). Krishnan et al. (2012) reported values between 0.230 and 0.300 for LE/Rn on grassland during the wet season in the semi-arid area of the United States. The ratio H/Rn was equal to 0.126 . In the dry period a change between the latent and sensible heat was observed, and the ratio $\mathrm{H} / \mathrm{Rn}$ became equal to 0.359 and due to the low content of available soil water the ratio LE/Rn was only of 0.001 .

Comparisons of estimated mean monthly ETo values using the temperature-based and radiation-based ETo methods are shown in the Figs 7, 8 and 9.

The Hargreaves-Samani and Makkink methods are suitable for predicting ETo in São João, Pernambuco when $\mathrm{Rn}, \Delta \mathrm{e}$ and $\mathrm{U}$ data are missing, as the Makkink method had better performance because due to a smaller root mean square error $\left(0.62 \mathrm{~mm} \mathrm{~d}^{-1}\right)$, while other methods had errors range from 0.94 to $1.18 \mathrm{~mm} \mathrm{~d}^{-1}$. 

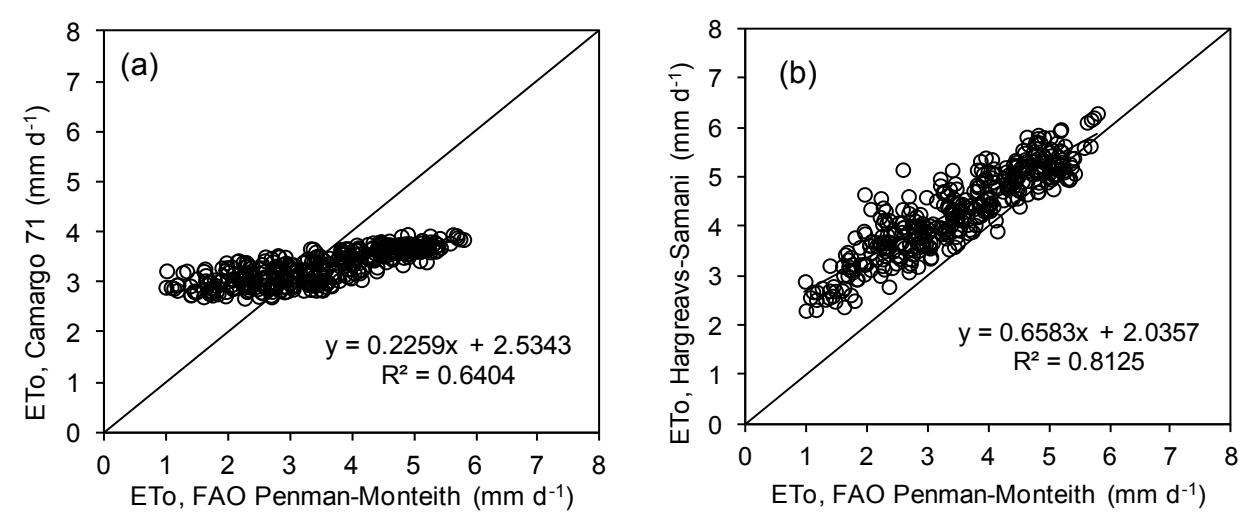

Fig. 8 Relationship between daily $\mathrm{ET}_{0}$ measured by Penman-Monteith-FAO estimated by the Camargo (a) and Hargreaves-Samani (b) methods.
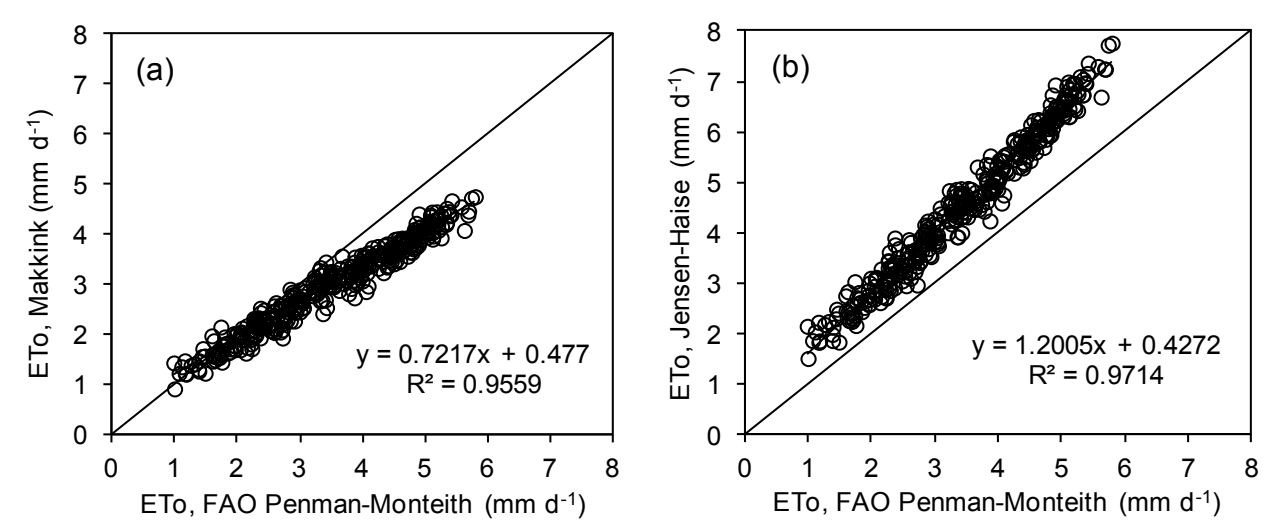

Fig. 9 Relationship between daily $\mathrm{ET}_{0}$ measured by Penman-Monteith-FAO and estimated by the Makkink (a) and Jensen-Haise (b) methods.

\section{CONCLUSIONS}

In Tapacurá basin, the Thorthwaite modified method performed better than the standard PenmamMonteith method. NDVI and NDWI were similar and presented consistent behaviour with other studies; the Beerkan method is a promising tool, robust and easy to use, which can help parameterization of hydrological models of the physical type and distributed.

In Pajeú basin, the flow of $\mathrm{CO}_{2}$ in the dry season showed lower fluctuations compared to the wet season, which presented the $\mathrm{CO}_{2}$ stream approximately three times the period of highest intensity (11:00 to 13:00 h); During the wet season, the largest fraction of the net radiation was converted to evapotranspiration process, whereas in the dry period this process was significantly reduced;

In Mundaú basin, the Makkink method performed better than the standard Penmam-Monteith method.

Acknowledgements The authors would like to thank the Brasilian Council for Scientific and Technological Development (CNPq), the Financier of Studies and Projects (FINEP), the Foundation for Science and Technology of Pernambuco State (FACEPE), Coordination for the Improvement of Higher Level (CAPES) and Pernambuco State Water and Climate Agency (APAC).

\section{REFERENCES}

Allen, R. G., Trezza, R. and Tasumi M. (2002) Surface energy balance algorithms for land. Advance training and user's manual, version $1.0,98 \mathrm{p}$.

Allen, R. G., et al. (1998) Crop evapotranspiration: guidelines for computing crop water requirements. FAO Irrigation and drainage Paper 56. FAO: Rome, 300p.Camargo, A.P. (1971) Balanço hídrico no Estado de São Paulo. Campinas: Instituto Agronômico, 24p. Boletim 116. 
Back, A. J. (2008).Desempenho de métodos empíricos baseados na temperatura do ar para a estimativa da evapotranspiração de referência em Urussanga, SC. Irriga 13(4), 449-466.

Braud, I., et al. (2005) Use of scaled forms of the infiltration equation for the estimation of unsaturated soil hydraulic properties (the Beerkan method). European Journal of Soil Science 56, 361-374.

Brooks, R. H. and Corey, A. T. (1964) Hydraulic Properties of Porous Media. Hydrology Paper, n.3, Colorado State University, Fort Collins.

Camargo, A. P., et al. (1999). Ajuste da equação de Thornthwaite para estimar a evapotranspiração potencial em climas áridos e superúmidos, com base na amplitude térmica diária. Revista Brasileira de Agrometeorologia, Santa Maria 7(2), $251-257$.

Carvalho, J. R. P., Silveira, P. M. and Vieira, S. R. (2002) Geoestatística na determinação da variabilidade espacial de características químicas do solo sob diferentes preparos. Pesquisa Agropecuária Brasileira 37, 1151-1159.

Costa, C. F. G., et al. (2013) Escoamento superficial em Latossolo Amarelo distrófico típico sob diferentes agroecossistemas no nordeste paraense. Revista Brasileira de Engenharia Agrícola e Ambiental 17(2), 162-169 (in Portuguese).

Fernandes, L. C. (2006) Avaliação de diversas equações empíricas de evapotranspiração. Estudo de caso: Campos dos Goytacazes e Ilha do Fundão-RJ. Tese (Doutorado) - Universidade Federal do Rio de Janeiro, 2006.

Gao, B. C. (1996) NDWI - A Normalized Difference Water Index for remote sensing of vegetation liquid water from space. Remote Sensing of Environment 58, 257-266.

Hargreaves, G. H. and Samani, Z. (1985) Reference crop evapotranspiration from temperature. Journal of Applied Engineering in Agriculture 1, 96-99.

Haverkamp, R., et al. (1994) Three dimensional analysis of infiltration from the disc infiltrometer. 2. Physically based infiltration equation. Water Resources Research, Washington, 30, 2931-2935.

Jensen, M. E. and Haise, H. R. (1963) Estimating evapotranspiration from solar radiation. Journal of Irrigation Drainage Division, ASCE, New York, 89, 15-41.

Krishnan, P., et al. (2012) Energy exchange and evapotranspiration over two temperate semi-arid grassland in North America. Agricultural and Forest Meteorology 153, 31-44.

Lassabatère, L., et al. (2006) Beerkan Estimation of Soil Transfer parameters through infiltration experiments — BEST. Soil Science Society of American Journal 70, 521-532.

Makkink, G. F. (1957) Ekzamento de la formulo de Penman. Netherlands Journal of Agricultural Science, Wageningen, 5, 290305 .

Markham, B. L. and Barker, L. L. (1987) Thematic mapper bandpass solar exoatmospherical irradiances. International Journal of Remote Sensing 8(3), 517-523.

Moura, A. R. C., et al. (2012) Evapotranspiração de Referência (ETo) segundo Thornthwaite Modificado, calibrado na bacia do riacho Gameleira - Estado de Pernambuco. Revista de Geografia (UFPE) 29(2), 153-167.

Pereira, A. R. and Pruitt, W. O. (2004) Adaptation of the Thornthwaite scheme for estimating daily reference evapotranspiration. Agricultural Water Management 66(2), 251-257.

Pereira, A. R. and Pruitt, W. O. (2004) Adaptation of the Thornthwaite scheme for estimating daily reference evapotranspiration. Agricultural Water Management 66(2), 251-257.

Rouse, J. W., et al. (1973) Monitoring the vernal advancement and retrogradation (green wave effect) of natural vegetation. Prog. Rep. RSC 1978-1. Remote Sensing Cent., Texas A\&M Univ., College Station.

Silva, R. M., et al. (2010c) Análise da variabilidade espaço-temporal e identificação do padrão da precipitação na bacia do rio Tapacurá, Pernambuco. Sociedade e Natureza 22(2), 357-372.

Silva, J. F. C. B. C. (2009) Análise espacial das características hidrodinâmicas e do uso e ocupação do solo da bacia experimental do rio Guaraíra mediante uso de geotecnologias. Dissertação de Mestrado Universidade Federal da Paraíba, João Pessoa, $85 \mathrm{p}$.

Souza, E. S., et al. (2008) Caracterização hidrodinâmica de solos: aplicação do método. Revista Bras. de Engenharia Agrícola e Ambiental. Campina Grande 12(2), 128-135.

Souza, E. S. (2005) Caracterização hidrodinâmica na escala local e da parcela agrícola de dois solos do estado da Paraíba: Variabilidade espacial e temporal, e meio homogêneo equivalente. Tese de Doutorado - Universidade Federal de Pernambuco, Recife, 138 p.

Souza, M. Z., et al. (2001) Variabilidade espacial de atributos físicos em um Latossolo Vermelho distrófico sob semeadura direta em Selvíria (MS). Revista Brasileira de Ciência Solo 25, 699-707 (in Portuguese).

Thornthwaite, C. W. (1948) An approach toward a rational classification of climate. Geographical Review 38, 55-94.

Van Genuchten, M. Th. (1980) A closed-form equation for predicting the hydraulic conductivity of unsaturated soils. Soil Science Society of America Journal 44, 892-898.

Vieira, S. R. (1997) Variabilidade espacial de argila, silte e atributos químicos em uma parcela experimental de um latossolo roxo de Campinas (SP). Bragantia 56, 181-190 (in Portuguese).

von Randow, C., et al. (2004) Comparative measurements and seasonal variations in energy and carbon exchange over forest and pasture in South West Amazonia. Theoretical and Applied Climatology 78, 5-26. 